\title{
THE GEOLOGY AND MINERALOGY OF THE ANURI KIMBERLITE, NUNAVUT, CANADA
}

\author{
Katya Masun, Buddy Doyle, Susan Ball and Sean Walker \\ Kennecott Canada Exploration Inc. Suite 354200 Granville Street, Vancouver, BC, V6C 1S4, Canada
}

\section{INTRODUCTION}

The Anuri kimberlite was discovered in 2001 by Kennecott Canada Exploration Inc. approximately 450 kilometres north of Yellowknife in Canada's Nunavut Territory (Figure 1). Anuri is positioned at the terminus of a well-defined kimberlite indicator mineral dispersion train, within the shallow, near-shore environment of Napaktulik Lake. Its discovery was the consequence of conventional till sampling techniques in combination with a ground-based gravity survey. The survey defined a $0.4 \mathrm{mGal}$ gravity low response which when drilled, intersected kimberlite. Follow-up ground geophysical work resolved a discrete non-magnetic break in a north-northwest trending magnetic dyke with a coincident conductor. Anuri intrudes Archean granitoid gneisses at the western edge of the northern portion of the Slave Structural Province, near the contact with Proterozoic supracrustal rocks of the Epwoth basin to the east. It is overlain by approximately 30 metres of glacial overburden consisting of poorly sorted Pleistocene boulder till, lake sediments and shattered subcrop of Proterozoic shale and siltstones.

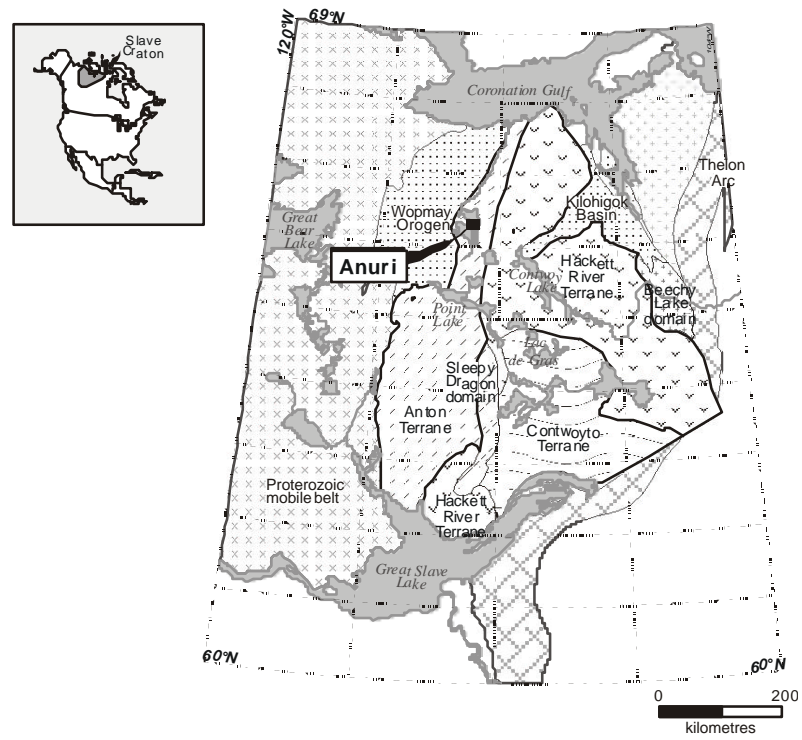

Figure 1. Slave Craton showing structural divisions (after Griffin et al., 1998) and the location of the kimberlite.

\section{KIMBERLITE MORPHOLOGY, PETROGRAPHY AND AGE OF INTRUSION}

Anuri does not outcrop at surface and kimberlite float is not known to occur within the local till cover; surficial exposure is confined to transported frost-heave regolith. Spatial distribution of infill and shape of the intrusion, at this stage, is largely conjectural due to limited exposure through drilling. However, it is speculated that at surface Anuri comprises a relatively large (4-5 hectares) volcanic edifice infilled with fragmental volcaniclastic kimberlite breccia to a known depth of at least 175 metres. Hypabyssal kimberlite intersected beneath the eastern lobe of Anuri, extends to a depth of at least 240 metres. Neither exploration drilling nor geophysical reconnaissance has established the geological relationship between the hypabyssal rocks and overlying volcaniclastic breccia, therefore age relations cannot be established.

Wallrock contacts intersected in exploration drill holes suggest that Anuri is a steep-sided (approximately 75$85^{\circ}$ ), coned-shaped vent that is ovoid in shape and elongated in an east-west direction in plan view surface expression. Fenitization forms an envelope about the complex. Locally the gneis sic host has been totally altered by alkali metasomatism and at some distances (up to 40 metres) from the intrusive contact, the alteration is readily recognizable as potassium feldspar overgrowths on the gneissic feldspar. Pronounced marginal hematization of crustal xenoliths and staining of open fracture surfaces is a commonly observed phenomenon within the vent infill.

The volcaniclastic kimberlite (VK) has been affected by a range of secondary alteration processes, including serpentinization, carbonatization, ferruginization (which tends to accentuate textural features of the rock) and clay formation; all resulting in the destruction of much of the primary mineralogy and textural features of the rock. Petrographically, VK comprises a serpentinized heterolithic fragmental rock composed a wide variety of crustal, mantle and cognate clasts. (both autoliths and vesiculated juvenile lapilli). Shallow 
kimberlite intersections are dominated by fragments of Paleozoic shale/siltstone, lesser granitoid, and smaller mantle-derived xenoliths and the products of their disaggregation (garnet, chrome diopside and oxides). Deeper intersections of VK are characterized predominately by xenoliths of Archean basement granitoid gneisses, less shale/siltstone and few mantlederived constituents. The volcaniclastic units of Anuri have been classified as resedimented heterolithic volcaniclastic kimberlite breccia.

Hypabyssal kimberlite (HK) occurs as a fine-grained dark gray rock containing macrocrystal olivine and abundant phlogopite and spinel in a fine-grained groundmass consisting of a second population of primary olivine, abundant barium-enriched phlogopite, lesser spinel and minor primary calcite, apatite and picroilmenite. Well-rounded, xenolithic fragments of host rock constitute less than $5 \%$ of the total volume of the rock and consist predominantly of granitoid fragments and lesser, smaller fragments Paleozoic sedimentary shales. Many of the granitoid clasts have been partially resorbed by the kimberlite magma. The sedimentary clasts have remained relatively unaltered. The preservation of delicate textures such as atoll spinels and the absence of any juvenile material support the classification of this rock as hypabyssal. More specifically, it can be termed a macrocrystic hypabyssal phlogopite spinel kimberlite. Diatreme facies (sensu Mitchell, 1995) or tuffisitic kimberlite (sensu Field and Scott Smith, 1998) has not been recognized.

Like many kimberlites, obtaining a reliable age of intrusion proved difficult for Anuri due to the paucity of minerals suitable for isotopic age determinations. A Neoproterozoic Rb-Sr model age of $613 \pm 6 \mathrm{Ma}$, derived from a single crystal of macrocrystal phlogopite from resedimented volcaniclastic kimberlite breccia of Anuri, represents the current best estimate for the age of intrusion. This age is unique compared with other kimberlites reported in Canada.

\section{MINERAL CHEMISTRY}

Heavy mineral concentrates, recovering paragenetic minerals with a specific gravity $2.89 \mathrm{~g} / \mathrm{cm}^{3}$ from crushed kimberlite rock, include garnet, spinel, ilmenite and clinopyroxene. Pyrope, Cr-spinel and clinopyroxene are abundant in VK concentrates, while Cr-spinel was the only kimberlite indicator mineral recovered of significance from HK. Pyrope and ilmenite are absent in the concentrates of the latter. In general, the bulk of kimberlite indicator minerals are of peridotitic parentage; xenocrysts of eclogitic origin are uncommon, limited to a nominal quantity of garnets.

\section{ILMENITE}

Monomineralic magnesian ilmenite, recovered in heavy mineral concentrates from VK can be subdivided into two groups based on major-element analyses: " $\mathrm{Cr}$ poor" and a "Cr-rich" population. The majority of analyzed grains fall into the former grouping. The " $\mathrm{Cr}$ rich" population represents late differentiates of the "Cr-poor" group and are characterized by $\mathrm{Cr}_{2} \mathrm{O}_{3}$ contents of $<2-\mathrm{wt} \%$ (predominantly <1wt\%) with corresponding $\mathrm{MgO}$ contents of $6-10-\mathrm{wt} \%$. The laterstage crystallizing ilmenite is characterized by $\mathrm{Cr}_{2} \mathrm{O}_{3}$ contents of 2-6-wt\% (but may be as high as 12-wt\%) and increase $\mathrm{Cr}_{2} \mathrm{O}_{3}$ is accompanied by a sympathetic increase in $\mathrm{MgO}$ (range from 9-12 wt-\% MgO).

\section{GARNET}

While pyrope garnet was recovered only from heavy mineral concentrates derived from VK, garnet of eclogitic paragenesis was recovered from both VK and HK. Garnet occurs as subangular anhedral grains, often altered at their margins. Compositionally, the

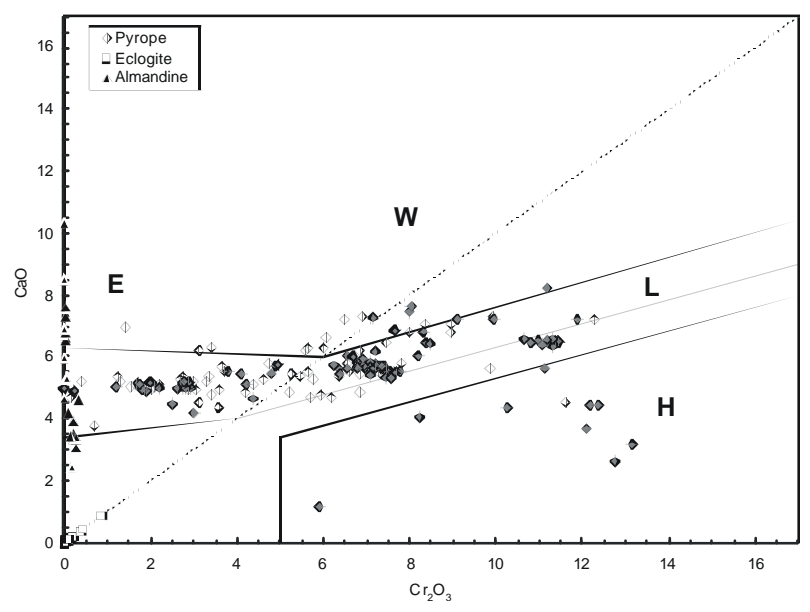

Figure 2. Composition of garnet recovered from heavy mineral concentrates from Anuri (after Sobolev, 1974).

$\mathrm{W}=$ Werhlite, $\mathrm{L}=$ Lherzolite, $\mathrm{H}=$ Harzburgote. $\mathrm{E}=$ Eclogite.

population is dominated by grains derived from mantle peridotites (Figure 2), primary lherzolite with lesser mineral grains of wherlitic and harzburgitic derivation (sensu Dawson and Stephens, 1975). A large majority of analyzed mineral grains are Cr-pyrope and uvarovite-pyrope solid solution garnet. Eclogitic garnet xenocrysts primarily include pyrope-almandine and megacryst-suite garnet containing relatively low sodium, generally less than $0.09-\mathrm{wt} \% \mathrm{NaO}$. 


\section{CLINOPYROXENE}

Monomineralic clinopyroxene and clinopyroxene intergrown or included within barite, sodic amphibole, chromite or phlogopite, was recovered in relative abundance from VK. There is a pronounced relationship between chrome and calcium content; $\mathrm{CaO}$ content decreases with increasing $\mathrm{Cr}_{2} \mathrm{O}_{3}$. A small population exhibiting both low chrome and low calcium is recognizable (CP2 Diopside; sensu Dawson and Stephens, 1975). The preponderance of clinopyroxene ( $80 \%$ ) classify as chrome diopside, of lherzolitic parentage. The remainder has chemistry consistent with diopside and ureyitic diopside of a megacryst paragenesis (Mitchell, 1986). Clinopyroxene is characterized by $\mathrm{Cr}_{2} \mathrm{O}_{3}$ content of $<4-\mathrm{wt} \%$ and $\mathrm{CaO}$ contents from 18-26-wt\%.

\section{SPINEL}

The presence of spinels is ubiquitous in both kimberlite rock types, occurring as macrocrysts, primary groundmass minerals, the products of the serpentinization of olivine and occasionally in association with ilmenite

\section{Macrocrystal Spinel}

Kimberlite indicator minerals recovered from heavy mineral concentrates are dominated by chromian spinel. Spinel macrocrysts occur as large (typically less than $2 \mathrm{~mm}$ ) rounded reddish-brown to deep brown-black grains that are distinguished from their primary groundmass counterparts on the basis of size and chemistry. These spinels essentially belong to the quaternary system spinel-magnesiochromite-chromitehercynite and are best described as magnesian

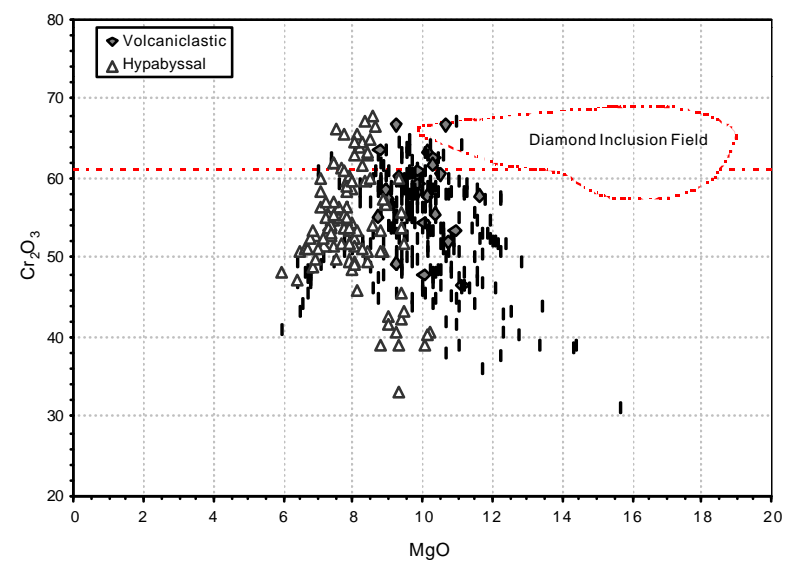

Figure 3. Composition of chromite plotted on the $\mathrm{Cr}_{2} \mathrm{O}_{3}$ $\mathrm{MgO}$ wt\% plot for chromites from Anuri (modified after Fipke et al., 1995). aluminous chromites. Individual crystals typically show weak zonation. $\mathrm{TiO}_{2}$ and $\mathrm{MgO}$ contents increase with evolution whilst $\mathrm{Cr}_{2} \mathrm{O}_{3}$ stays relatively constant or may increase slightly.

Evolutionary trends in both $\mathrm{HK}$ and VK Cr-spinel are similar, although the chemistry of the former is significantly more constrained, especially with respect to $\mathrm{MgO}$ (see Figure 3). $\mathrm{TiO}_{2}$ enrichment, seen in both populations is the likely result of macrocrystal spinel cores overgrown and/or reacting with high- $\mathrm{TiO}_{2}$ microphenocrystal spinel crystallizing from the magma.

\section{Groundmass Spinel}

Small $\quad(<0.1 \mathrm{~mm})$ euhedral-to-subhedral spinels comprise a significant portion of the groundmass mineral assemblage of both VK and HK rock of Anuri. Their abundance, in general, is homogeneous, typically accounting for $5-\mathrm{vol} \%$ of the rock. Primary groundmass spinel occurs as discrete homogeneous or complexly zoned crystals, which have been subjected to a varying degree of resorption. Homogenous euhedral spinels also occur as inclusions in microphenocrystal olivine and are essentially identical in composition to their macrocrystal complement. Within HK, spinel abundance may vary locally owing to concentration by preferential nucleation about preexisting olivine or the (minor) presence of oxide-free calcite-serpentine segregations. Resorption of complexly mantled minerals in HK results in atoll-textured spinels. Two separate evolutionary trends of primary magmatic spinels are evident within the Anuri kimberlite: Magnesian Ulvöspinel Magmatic Trend and Titanomagnetite Magmatic Trend (Figure 4).

\section{Magnesian Ulvöspinel Magmatic Trend}

Magmatic spinel of this trend, present in both HK and $\mathrm{VK}$, is an evolution of titanian magnesian aluminous

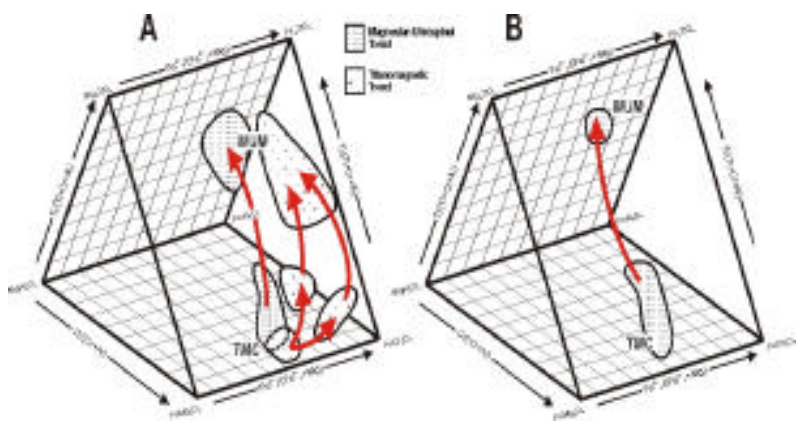

Figure 4: Compositional trends of spinels plotted onthe reduced iron spinel prism (after Mitchell and Clarke, 1976) from Anuri volcaniclastic (A) and hypabyssal (B) kimberlite. 
chromite or titanian magnesian chromite towards members of the magnesian ulvöspinel-ulvöspinelmagnetite solid solution series. It is a trend of increasing $\mathrm{Ti}$, total $\mathrm{Fe}$ and decreasing $\mathrm{Cr}$ at approximately constant $\mathrm{Fe} /(\mathrm{Fe}+\mathrm{Mg})$ Spinel crystallization commenced with relatively $\mathrm{Al}_{2} \mathrm{O}_{3}$-poor aluminous magnesian chromites (relative to spinels of similar $\mathrm{Ti}$ content in kimberlite) and evolved to titaniferous magnesian chromite. Continued increasing $\mathrm{Ti}$ and $\mathrm{Fe}^{3+}$ at approximately constant $\mathrm{Fe} /(\mathrm{Fe}+\mathrm{Mg})$ ratios results in the crystallization of members of the magnesian ulvöspinel-ulvöspinel-magnetite series. Tifree magnetite does not terminate the spinel compositional trend. A distinct hiatus in the crystallization sequence, likely reflecting a miscibility gap is a hallmark of this spinel trend. Compositional evolution of this magmatic trend is similar to those determined in other kimberlites worldwide, and is essentially equivalent to magmatic trend 1 described by Mitchell (1986).

\section{Titanomagnetite Magmatic Trend}

Magmatic spinel of the titanomagnetite magmatic trend is only found in volcaniclastic rocks. This trend is equivalent to Mitchell's (1986) magmatic trend 2 and is less commonly described in kimberlites than the magnesian ulvöspinel magmatic trend. It involves the evolution of titanian magnesiochromite-chromite solid solutions towards magnesian ulvöspinel-ulvöspinelmagnetite solid solutions involving an increase in $\mathrm{Fe}^{2+}$, $\mathrm{Fe}^{3+}$ and $\mathrm{Ti}$ with concomitant decrease in $\mathrm{Cr}$ and $\mathrm{Al}$. Spinel compositions are depleted in $\mathrm{Al}$ and are characterized by rapid decline in $\mathrm{Mg}$ with evolution.

\section{MICA}

Mica is uncommon within the volcaniclastic infill of Anuri. Where they are evident, macrocrystal laths are partially-to-wholly altered by chlorite and serpentine and are commonly broken and kinked, exhibiting strained extinction. Small, microphenocrystal phlogopite occurs as a minor component strewn throughout the groundmass. Conversely, hypabyssal kimberlite is characteristically micaceous. Phlogopite occurs as a major primary groundmass phase in the form of small tabular-to-lath shaped microphenocrysts, typically less than $100 \mu \mathrm{m}$ in length. Pale green chlorite and lesser calcite + serpentine replacement is common. Phlogopite poikilitically encloses small euhedral crystal now wholly replaced by serpentine. The result is a sugary-granular text ure similar to that described within the groundmass of many Lac de Gras kimberlites, where the euhedral grains are recognized as monticellite (Masun, 1999). Evolution of primary groundmass phlogopite is found to be from phlogopite to aluminous phlogopite and plot along a "kimberlite" trend as defined by Mitchell (1986).

Analysis of mica in both $\mathrm{HK}$ and VK of Anuri reveals a distinct enrichment in $\mathrm{BaO}$ (ranging from 0.05 to 11.3wt $\%$ ) and they can be thus described as members of the phlogopite-kinoshitalite solid solution series. $\mathrm{BaO}$ shows a systematic increase from the core (generally $<1-\mathrm{wt} \%$ ) to the mantle (up to $11-\mathrm{wt} \%$ ) of individual, zoned crystal. This enrichment is analogous to that observed within the Lac de Gras kimberlite field (Masun, 1999), although Anuri, unlike the Lac de Gras intrusions, contains a second population of low chrome titaniferous phlogopite. Not enough data exists to accurately delineate this population.

\section{LITHOSPHERIC STRUCTURE}

The lithospheric mantle beneath Anuri is comprised of two distinct layers, comparable to that for the central Slave Craton (Griffin et al., 1998). It is comprised of a depleted upper layer and a less depleted lower layer separated by a sharp boundary at a depth of about 150 kilometres (Internal Report prepared by W.L. Griffin). Trace element geochemistry of garnets derived from heavy mineral concentrates define a stepped geotherm near $35 \mathrm{~mW} / \mathrm{m}^{2}$, with the base of the lithosphere lying at a depth of at least 180 kilometers. Xenocrystal garnets derived from the deep layer reveal a sinuous REE patterns typical of diamond-related garnet, shown by the combination of high $\mathrm{Sc} / \mathrm{Y}$ and high $\mathrm{Nd} / \mathrm{Y}$. The main disparity from the central Slave section is the dominance of depleted lherzolite, rather than harzburgite in the upper layer. This leads to the speculation that a boundary between the central Slavetype of lithosphere and a less depleted more metasomatized mantle lies further north of the Anuri kimberlite. It is therefore plausible that Anuri may have a comparable diamond grade to many of the diamondiferous kimberlites of the central Slave.

\section{DISCUSSION}

\section{ROCK-TYPE CLASSIFICATION}

The modal mineral assemblage and textures observed both macroscopically and microscopically together with the presence of a typical kimberlitic indicator mineral suite support the classification of Anuri as a kimberlite. Furthermore, the examination of the primary mineral assemblage demonstrate evolutionary trends 
characteristic of kimberlite. Specifically, the magnesian ulvöspinel trend exhibit in groundmass spinels is exclusive to kimberlite and the evolution of primary groundmass mica from phlogopite to aluminous phlogopite plots along the "kimberlite" trend on the $\mathrm{Al}_{2} \mathrm{O}_{3}$ vs. $\mathrm{TiO}_{2}$ discrimination diagram. These features, in conjunction with the paucity of any atypical typomorphic minerals in the primary mineral assemblage permits Anuri to be classified as a bona fide kimberlite as defined by Woolley et a.l (1996).

\section{MODE OF FORMATION AND KIMBERLITE EMPLACEMENT}

The two rock types recognized in Anuri are texturally disparate and mineralogically distinct, indicating different styles of kimberlite emplacement and deposition. Hypabyssal kimberlite is distinguished by a higher magnetic susceptibility and a strongly contrasting population of mantle-derived xenocrysts. Moreover, the proportion, type and alteration of crustalderived xenoliths and the nature of the inter-clast matrix further support different modes of emplacement. The hypabyssal rock is strikingly micaceous and contains conspicuously fewer mantle- and crustal-derived xenoliths and xenocrysts and a larger proportion of Archean crystalline basement fragments.

\section{Volcaniclastic Kimberlite}

It is proposed that the emplacement of Anuri is analogous to that postulated for many kimberlites in the Lac de Gras field, (e.g., Graham et al., 1998) that is, near-surface, high energy explosive excavation of the volcanic edifice with ensuing vent infill. The country rock that once occupied the excavated crater was expelled and accumulated, together with kimberlite ejecta, as extra-crater deposits. As the locus of explosive fragmentation descended, the volcanic vent was progressively deepened, combining juvenile magmatic fragments with slumping material from extracrater deposits and material deposited along the crater wall as an inner tuff ring. This resulted in the development of a massive, poorly sorted volcanic pile. Resedimenation of crater material was likely achieved by mass wasting and proximal debris flow allowing thick beds composed of a randomly-oriented clastic component supported in a fine-grained matrix. Some Locally-observed nebulous orientation of elongated constituents, possibly defining basal contacts of largescale units, is consistent with debris flows. There is no evidence of in situ primary pyroclastic kimberlite within the intra-crater deposits, although this may simply be a consequence of poor exposure.

\section{HYPABYSSAL KIMBERLITE}

The hypabyssal kimberlite occurs as an intrusive unit. No evidence suggests that it underwent explosive fragmentation during vent emplacement. Although there is no evidence of VK "grading" into $\mathrm{HK}$, intersection of $\mathrm{HK}$ was limited to a single drill hole. However, the presence of virtually unaltered Proterozoic sedimentary fragments, which geological relationships suggest could only be derived from above, suggest that the HK represents a feeder dyke or root to the Anuri VK. 


\section{REFERENCES}

Dawson, J.B., Stephens, W.E. 1975. Statistical analysis of garnets from kimberlites and associated xenoliths. Journal of Geology 83, 589-607.

Field, M., Scott Smith, B.H., 1998. Contrasting Geology and Near-Surface Emplacement of Kimberlite Pipes in Southern Africa and Canada. In: Proceedings of the VIIth International Kimberlite Conference, Gurney, J.J, Gurney, J.L, Pascoe, M.D., Richardson, S.H. (Eds.), Red Roof Design cc, Cape Town, South Africa, pp. 214-237.

Fipke, C.E., Dummett, H.T., Moore, R.O., Carson, J.A., Ashley, R.M., Gurney, J.J., Kirkley, M.B., 1995. History of the discovery of diamondiferous kimberlites in the Northwest Territories, Canada. Extended Abstracts of the Sixth International Kimberlite Conference, Novosibirsk, Russia. pp. 158160.

Graham, I., Burgess, J.L., Bryan, D, Ravenscoft, P.J., Thomas, E., Doyle, B.J., Hopkins, R., Armstrong, K., 1998. Exploration History and Geology of the Diavik Kimbelites, Lac de Gras, Northwest Territories, Canada. In: Proceedings of the VIIth International Kimberlite Conference, Gurney, J.J, Gurney, J.L, Pascoe, M.D., Richardson, S.H. (Eds.), Red Roof Design cc, Cape Town, South Africa, pp. 262-280.

Giffin, W.L, Doyle, B.J., Ryan, C.G., Pearson, N.J., O’Reilly, S.Y., Natapov, L., Kivi, K, Kretschmar, U., Ward, J., 1998. Lithosphere Structure and Mantle-Derived Xenocrystic Garnets. In: Proceedings of the VIIth International Kimberlite Conference, Gurney, J.J, Gurney, J.L, Pascoe, M.D., Richardson, S.H. (Eds.), Red Roof Design cc, Cape Town, South Africa, pp. 299-306.

Masun, K.M., 1999. The Petrography and Mineralogy of the Lac de Gras Kimberlite Field, Slave Province, Northwest Territories: A Comparitive Study. M.Sc. Thesis, Lakehead Univ. Thunder Bay, Canada.

Mitchell, R.H., 1986. Kimberlites: Mineralogy, Geochemistry and Petrology. Plenum Press, New York.

Mitchell, R.H., 1995. Kimberlites, Orangeites, and Related Rocks. Plenum Press, New York.

Mitchell, R.H., Clarke, D.B., 1976. Oxide and sulphide mineralogy of the Peuyuk kimberlite, Somerset Island, N.W.T., Canada. Contributions to Mineralogy and Petrology 56. 157-172.
Sobolev, N.V., 1974. Deep seated inclusions in kimberlites and the problem of the composition of the upper mantle. English edition translated by D.A. Brown 1977. American Geophysical Union, Washington D.C. pp. 279.

Contact: Katya Masun, Suite 354200 Granville Street, Vancouver, BC, Canada, V6C 1S4, E-mail:

katya.masun@kennecott.com 